\title{
Analysis on National Defense Education and Construction of National Defense Associations in China
}

\author{
Han Wang, Yi Zhuo \\ Business School Finance Management, Hohai University, Nanjing, China \\ Email: 1246872320@qq.com, zy99619@163.com
}

How to cite this paper: Wang, $H$. and Zhuo, Y. (2018) Analysis on National Defense Education and Construction of $\mathrm{Na}$ tional Defense Associations in China. Open Journal of Social Sciences, 6, 85-94. https://doi.org/10.4236/jss.2018.68006

Received: July 16, 2018

Accepted: August 13, 2018

Published: August 16, 2018

Copyright ( 2018 by authors and Scientific Research Publishing Inc. This work is licensed under the Creative Commons Attribution International License (CC BY 4.0).

http://creativecommons.org/licenses/by/4.0/

\begin{abstract}
National defense education is a major issue that cannot be ignored by all countries. University defense associations are important carriers for students to carry out their own national defense education activities, especially in the second classroom of the university. However, its functions have not been effectively played. This paper analyzes the development status and reasons of defense associations, and explores the significance and development path of national defense education activities under the second classroom transcript system.
\end{abstract}

\section{Keywords}

The National Defense Student Associations, The Second Classroom, Communist Youth League, National Defense Education, Second Classroom Transcript, Construction, Spirit of Patriotic

\section{Introduction}

The report of the 19th National Congress of the Communist Party of China clearly showed that our national defense needs all citizens join, and we must strengthen national defense education for all. National defense education for college students is an important part of national defense education. At this stage, China is in an important stage of transforming from a large country of higher education to a country with a higher education. The quality of higher education has been greatly improved. It is not only popularizing nine-year compulsory education in cultural education, but also advancing to the 12-year compulsory education. It has also invested a great deal of energy in national defense education, which has made students' feelings and patriotism upgraded. As the most 
important way for colleges to cultivate practical and innovative talents, the second classroom has attracted more and more attention. Its function and role in educating people have become increasingly prominent. University defense students' associations should play an irreplaceable role in carrying out patriotism education and revolutionary traditional education, cultivating and improving students' feelings in loving home and country. However, due to the irregular development of the organization, it is not only in the second classroom function. The continuation of the association itself has problems. The second class of college students is compared to the first class based on classroom teaching. The essence of the second class is to let students with the same interests share each other, inspire each other, think independently, develop and innovate, improve students' thinking ability, and apply the theory learned in the first class to the practice of the second class. University defense student associations are an important category in the organization of college student organizations. They are widely found in colleges and universities at all levels and in all regions. They are the main force in carrying out national defense education activities in the second classroom. At present, most college defense student associations play poorly. Yang Bo, A military teaching and research expert at Southeast University, mentioned in his article that military and national defense entered college education to promote the reform and innovation of the military structure while cultivating the awareness of contemporary youth defense. The positive change is to make more young people join the army. Thereby stepping up the military strength and stabilizing national strength. In many second class studies, Zhou Yi once mentioned in her research that the second class and the college student community are to help students develop self-management awareness while having stronger cohesiveness and influence, which is beneficial to Students quality developing and knowledge teaching.

These two points are very important in modern college education. The author combines them with knowledge and theory, to find the most suitable education method for the combination of national defense and the second classroom in modern college education, so as to improve the teaching in colleges and universities efficient, and improve students' interest in learning.

\section{The Significance of Carrying out National Defense Education Activities Based on the Second Classroom Transcript System of the Communist Youth League in Colleges and Universities}

In the report of the 19th National Congress, the military and youth are the key words [1]. The President Xi Jinping also served as the first secretary of the County People's Armed Forces and the first political commissar when he was transferred from the army to Zhengding as the county party secretary. He has been always keeping it importance to the party's armed work for many years. The party has always appeal us to pay attention to the youth and believe in the youth. On the occasion of the May 4th, Youth Day, the general secretary work 
with the youth and give eager hope to the youth. The reply to the newly enrolled college students of Nankai University this fall shows the importance attached by the General Secretary to youth and armed work. As the party's assistants and reserve army, the party's group organization, the Communist Youth League organizations, especially the college youth league organizations should rely on the second class transcript system of the Communist Youth League of colleges and universities to build a good defense student community in colleges and universities, and do a good job in national defense education. The following four points show the significance of building a national defense student association based on the second classroom transcript system of the Communist Youth League.

\subsection{Concrete Measures to Deepen the Reform of the Communist Youth League}

National defense education is not only the first classroom education, just a simple military training and military theory courses, but a series of educational activities centered on patriotism. It include so many section. It involves everything related to national defense directly or indirectly, including theory, the spirit, knowledge, skills and other aspects are the educational work that the Party and the president Xi Jinping have always attached importance to. At present, most of the college students born after 1995, and the freshmen are mostly born after 2000. Such a wide and rich content, and such an active group of college students, it is difficult to achieve the expected results by just one educational method. In colleges and universities, multi-sector cooperation must be done to complete.

As the extension and supplement of the first class, the second class is an important part of the university education system. Its activities can be divided into four major categories: social practice in the summer and winter vacation, participation in the campus cultural activities, innovation and entrepreneurship competition and social work and skills training. Since 2014, the Communist Youth League has gradually carried out the pilot construction of the second classroom transcript system throughout the country. Through the construction and promotion of the second classroom transcripts of the students, the university has created a rich and colorful campus culture and comprehensively assisted the students' comprehensive quality education. Hohai University, University of International Business and Economics, Nanjing University of Technology and many other pilot school have achieved the process control of the second classroom activities of students through the assessment on the PU platform (a platform on internet for student in school), and promoted the curriculum and teaching efficiency of the group activities.

The constitution of the communist youth league stipulates that we must hold the banner of patriotism, educate the members and young people to learn from the revolutionary predecessors, inherit the brilliant traditions of the party, and carry forward the socialist morality. Therefore, it is an indispensable responsibility of the Communist Youth League to carry out national defense education in 
colleges and universities and build a national defense student association in colleges and universities. It is a concrete measure to implement group reform.

\subsection{Cultivate and Enhance Students' Feelings in Their Home and Country}

National defense education should be in the mind and in the heart. For college students, it is not only to satisfy the curiosity of military personnel and weapons and equipment, but also to further guide the rise to the sense of responsibility and mission of loving school, patriotism, and loving the party, and then cultivate and improve the feeling of home and country. The way to cultivate the feelings of college students' homeland includes the improvement of the second classroom in the main channels of classroom teaching. Generally speaking, at the beginning of the formation of the society, the sponsors of the national defense student associations of the university often pay attention to the national defense education and patriotism education for the students. The first generation of sponsors often have a strong sense of mission and sense of responsibility, they are carried through various activities carried out by themselves, and subtly promote the feelings of the country. I hope that this strong sense of responsibility can be achieved once and then passed down. By joining the association or participating in the club activities, students can be together with others and have a strong sense of responsibility. In the process of communication, they will enhance their national defense awareness and cultivate their love of country.

\subsection{Promoting the Construction of Campus Culture to Create a National Defense Atmosphere}

Campus cultural resources exist in university, and college defense student associations can use campus cultural resources for national defense education conveniently and efficiently [2]. At the same time, the campus culture has the characteristics of sustainable use, which makes up for the shortcomings of short-term national defense education and relatively concentrated education. Campus culture can enable college students to receive national defense education from psychology, material, system and behavior, to achieve the useful result of national defense education, rather than cramming education, and greatly improve the effectiveness of national defense education. Through the educational role of campus culture and the superiority of the second classroom transcript system, it is a good way to infiltrate the national defense education into all aspects of the study, life and entertainment activities of the majority of college students.

\subsection{Assisting the Military Teaching and Recruitment Work of the School}

Military courses are divided into military skills training and military theory courses. According to relevant laws and regulations, military courses are compulsory for college students. The state hopes that through military education, 
students will acquire basic military skills and knowledge, develop basic military literacy, enhance the national defense concept for young college students, and cultivate their sense of responsibility and mission. Military theory education is the first classroom, and the student association is a form that college students are willing to accept education. It can actively influence and make the participation of students in national defense education. Conducting national defense education in the second classroom provides a strong guarantee for the improvement and innovation of military teaching in colleges and universities. The party's strong military goal in the new era calls for more aspiring young people to join the army and summon high-quality college students to join the army. From the perspective of talent cultivation [3], college defense student associations carry out activities in the second classroom, which expands the knowledge system of college students and provides favorable conditions for the further development of college students. It is indispensable for college students' quality education. One key can make more college students pay attention to national defense and even join the army. This will have a profound impact on national defense and military modernization.

\section{The Current Situation and Reasons for the Integration of National Defense Student Associations into the Second Classroom}

\subsection{Situation Analysis}

Through investigations, it is found that the current national defense student associations are mainly divided into seven categories. The first five types of associations can organize activities with extensive participation, which can be used as the main force for the national defense education of college students in the second classroom. The details are as follows:

The National Defense Association and the National Defense Education Association, which are led by the armed departments of universities, with the mission of popularizing national defense education. As a task of assisting the armed forces of colleges and universities, such as conscription propaganda and military training, this type of organization is defined between the student department and the student community, which is the main force for the second classroom to carry out national defense education. However, most national defense associations and national defense education associations help the People's Armed Forces in organizing activities only during recruitment and military training, what's more, the activities are relatively simple and the number of participants is small. The standard defined by the Association of Military Fans is whether the focus of work is based on the work of the armed forces of colleges and universities. It is worth noting that some of the defense associations of colleges and universities are actually military enthusiasts associations, mainly designed for communication, which rarely assist the armed departments of colleges and universities.

A student instructor group responsible for student military training, which is headed by the college academic department, the armed department, and the se- 
curity department. Due to the expansion of enrollment and military reform in colleges and universities, the drillmasters of the military training units of colleges and universities are insufficient. Thus some colleges and universities (mainly based on the second batch of undergraduate) began to form their own student instructors, with veterans as the core, recruiting outstanding college students, training in the summer, to train freshman in the new semester began and assist the school's security work. It plays a better role in military training, but there are fewer national defense education activities in the second classroom.

Special student associations composed of students with special links to national defense construction. For example, the veteran association consisting of college veterans, the national defense associations with defense students, and the national reserve soldiers with national defense reserve students (mainly from technical colleges). Although the discipline is strict, it is generally a small group whose activities are generally not for the whole school.

The national flag escort with the mission of guarding the national flag led by the school's armed forces. The National Flag Guards cover a wide range and are available to almost all colleges and universities. They play an irreplaceable role in promoting the spirit of patriotism. They are students wearing uniforms on campus.

The student associations headed by the school sports department, with certain military sports skills as the core, such as shooting teams and directional cross-country teams. Such associations have developed better with the support of the school sports department, but are busy with competition training and have fewer activities in the second classroom. If the school sports department does not support military sports, the daily professional training funds cannot be solved, and the development prospects are worrisome.

Student associations headed by school sport apartments with some military sports skills as their core, such as shooting teams and directional cross-country teams. Such associations have developed better with the support of the school sports department, but are busy with competition training and have fewer activities in the second classroom. If the school sports department does not support military sports, the daily professional training funds cannot be solved and the development prospects are worrisome. Student associations formed by diplomatic interest associations, such as the Model United Nations Association and the Military Diplomacy Association. Aim to exercise the overall quality of students, but the number of participants is limited and the cost is high [4].

Military enthusiasts and CS associations mainly consist of military fans which are interested in a military skill. Mainly to provide the military fans with a platform for communication, and activities are mostly military salons, live-action CS, etc. If military fans have military enthusiasts such as "over the wall party", they may be involved in secrets.

\subsection{The Reason why National Defense Student Associations Are Difficult to Integrate into the Second Classroom}

The school's armed work system has led to a lack of strong guidance to the 
community. Most college defense student associations have complex subordination relations and have little contact with the group learning system. The seven types of associations have different affiliations. Apart from Nanjing University, there are fewer colleges and universities have independent People's Armed Forces Office. The armed departments of the school cooperate with the student management department or the security department. The limited number of armed workers is the result of conscription and military training. Moreover, a small number of colleges (mainly private universities) have not even established armed departments with party committees or administrative systems. Therefore, the armed forces have not paid enough attention to the integration of the national defense student associations into the second classroom [5].

Most college defense student associations face the same lack of vision and mission values as other ordinary student organizations, with strong randomness and poor continuity. Due to the lack of strong leadership or guidance from the school sector, the current national defense student associations have greater autonomy [4]. The internal management and activities are generally determined by several key leaders of the association at that time. They often lack long-term planning and long-term goals, and cannot do "a blueprint to the end". Therefore, the rise and fall of the association is tied to the main responsible person. If the person in charge is more comprehensive, the development will be better. On the contrary, if the successor's comprehensive ability is not strong, there will be a bad situation.

Internal management lacks a chapter to establish regulations, and management is not standardized in actual operations. At the beginning of the establishment of defense students' associations in colleges and universities, they often work on the basis of simple agreement and mutual trust of members. Students' participation and withdrawal are arbitrary, where internal self-discipline is relatively weak, and there is no awareness of establishing regulations. After the development of the community is mature, it is often centered on several major rules that are customary. When dealing with specific problems, there is a lack of normative incentives and constraints. Even if some person in charge of the association has established rules and regulations, it is difficult to continue because the system is immature, unscientific, and non-standard, or because the follow-up responsible person will abandon it, and the regulations cannot be well implemented and passed down.

Lack of effective external management. The management organization's overall coordination capacity is weakened. With the development of colleges and universities and the increasing demand for individualized students, there are more and more types of national defense student associations, and their functions overlap. The repetition rate is often high when carrying out activities. Even in some colleges and universities, there are vicious competitions such as disorderly looting members, malicious slander, and destruction of similar activities. Some colleges and universities do not pay enough attention to the development 
of the community. There is a lack of effective supervision and management in the whole life management cycle chain such as the registration, daily management and cancellation of associations. For example, the materials submitted by the association have not been carefully reviewed and approved. The daily management of the association relies heavily on the student associations such as the Association of Societies, and the related management regulations are mechanically out of date. There is no substantive consideration about how to promote the scientific development of the association and protect the rights and interests of the association. Therefore, it is not only unable to obtain effective support when the development of the society is difficult, but also there is no severe punishment for the violations of the society.

Insufficient supply of resources leads to limited sustainable development. College defense students' associations often need more teachers, materials and other aspects than ordinary organizations. Especially at the beginning of the establishment of the association, it is difficult to survive without corresponding support. Not only that, the daily training venues, office space, and material storage rooms of the association are also important factors that restrict the development of the association. Therefore, to achieve the long-term development of national defense student associations, a strong management department is needed.

\section{How to Effectively Build College Defense Student Associations}

According to these universal problems faced by the national defense student associations in colleges and universities, three development suggestions are proposed.

\subsection{Scientific Management and Perfect System}

First, the Communist Youth League of the school takes the lead in coordinating the research of the propaganda department, the academic department, the armed department, the sports department, and the security department system of the school to formulate the planning and implementation plan for the construction of national defense student organizations in colleges and universities, which designed to be a construction guidance document for the defense associations of colleges and universities [6]. The second is to establish a scientific and rational policy orientation, encouraging national defense student associations and other ordinary student associations to carry out national defense knowledge popularization and visit veterans' social practice activities through evaluation and evaluation. Through the punishment and elimination mechanism, the violation of discipline and discipline society will be dealt with seriously, and a good environment will be established for the development of school associations. [6] Third, a new student department should be set up to manage the defense student associations in colleges and universities. The college youth leagues and other 
departments of the university have limited staffing so that it is difficult to draw special person to manage. The backbone of the major student organizations should be expanded to the National Defense Association, and the National Defense Association should be reorganized into a student department, giving the major students a high-quality treatment. Absorbing outstanding young students to join the school's national defense education, supervising the school's national defense student associations, and shouldering the functions of guiding the school's student departments, student associations, and league branches to carry out national defense education activities.

\subsection{Strive for External Support and Seek Development Resources}

First, they should rely on regional associations to strengthen inter-school exchanges and cooperation. For example, Jiangsu Province has established the National Defense Education Research Committee of the Jiangsu Higher Education Society. It organizes the selection of Jiangsu Military Training Stars, national defense education essays and other activities throughout the year. It promotes development. The second is to take military training and military theory courses as an opportunity to carry out military-school cooperation [7]. All colleges and universities have cooperated with major military training bases, various units, and military academies in military training and military theory courses. They can hire their quality instructors to form a team of outside tutors to conduct business guidance. The third is to rely on alumni to carry out school-enterprise cooperation. Many college alumni have the enthusiasm to donate funds to the school. A platform for college student associations-enterprise cooperation alliances should be established. In addition to the unpaid donations, the school-wide and regional activities carried out by the association can promote the development of the enterprise and strive for certain financial support. The research and innovation achievements carried out by the association can also cooperate with the enterprise to go to the market. The fourth is to assist the school department's work to get support. For example, you can work with libraries to host revolutionary book recommendation activities.

\subsection{Strengthen Internal Construction and Enhance Sustainable Development}

The first is to establish a team culture system consisting of the association's charter, social banner, emblem, social training, charter, core concept, etc. With the soul of the team, this society has a life-long spirit [8]. The second is to improve the organization's procedures and development plans, and regulate the daily activities, the change of the way, the probation period, and the hiring of the instructors. It is important to design the short-term medium-term and long-term development goals of the development of the association to achieve sustainable development of the association. Finally, it is necessary to highlight the characteristics and form the core competitiveness of the community. 


\section{Conclusion}

National defense education in colleges and universities is the foundation of national defense education for all, and General Secretary Xi has high hopes for this. The second classroom transcript system created by the Communist Youth League of colleges and universities makes the work of the Communist Youth League fully covered, and the national defense education work should rely on the second classroom transcript system to take advantage of the wind. National defense student associations are the specific implementer. College youth leagues should be concerned about the second classroom transcript system of college defense student associations, thus promoting national defense education.

\section{Conflicts of Interest}

The authors declare no conflicts of interest regarding the publication of this paper.

\section{References}

[1] Xinhua News Agency (2015) Xi Jinping Stressed at the Central Party's Group Work Conference: Effectively New Situation. People’s Daily, Beijing, 2015-07-08 (001).

[2] Hu, X.B. (2008) Research on the Value of National Defense Education in College Students' Ideological and Political Education. Master Thesis of Central South University, Changsha, No. 11.

[3] Zhou, C.L. (2013) Study on the Satisfaction of Talent Cultivation Quality in Colleges and Universities Based on Stakeholder Theory. Journal of North China Electric Power University (Social Science Edition), No. 04.

[4] Pei, P. (2017) Relying on National Defense Associations to Promote the Development of Comprehensive Quality Training in Colleges and Universities. Yangtze River Series, 24.

[5] Li, J. (2013) Exploration and Practice of Building Culture in the Construction of National Defense Students. Culture and Education Materials, 18.

[6] Zhang, X.Q. (2005) Discussion on Some Issues of National Defense Education in Colleges and Universities under the New Situation. Journal of Nanjing Institute of Technology (Social Science Edition), No. 03.

[7] Li, K., Zhang, Z.M. and Qi, H.B. (2015) The Innovation Path of National Defense Education Model in the Perspective of "Overall National Security Concept. Journal of Yangzhou University (Higher Education Research Edition), No. 02, 63-66.

[8] You, B. (2015) On the Effective Path of National Defense Associations in Promoting National Defense Education. Innovation and Entrepreneurship Education, 6. 